monolithic, central command for all the unions. The reality is quite different, with independent, autonomous international unions and a relatively weak national center. And within and among American unions, a wide range of political and economic views exist. Also, old leaders, their vision shaped by World War II, the Cold War, and the economic "good times" of the 1950s and 1960s, are being replaced by newer leaders, shaped by the civil rights and anti-war movements, Watergate, and the Reagan era. This surprised CGT leaders.

Members of the American group also met with French workers employed in similar sectors. For example, American and French health-care workers met. I met with CGT members at the Case-Poclain plant, a firm that manufactures excavating equipment and is owned by the Tenneco Corporation. They have been hurt by the recession: 241 of the eight hundred workers had recently been laid off. It was unclear whether anyone would be called back to work. We discussed seniority clauses and how hard it was for laid-off workers to find well-paid jobs. The discussions were warm and comradely. Following the meeting, the CGT union at Case-Poclain issued a statement of solidarity with American workers, calling on workers to unite across borders to defend themselves against multinationals.

A meeting with CGT Secretary-General Henri Krasucki focused on ways to develop lines of communication between French and American workers. One suggestion was to develop union-to-union contacts. Another was for labor-studies programs to promote communication with the CGT within the context of "solidarity across borders" and the global economy. A related approach might be to identify American and French firms owned by the same multinational corporations and to foster communication between both unions to promote a united front against global whip-sawing. Finally, it was suggested that the CGT communicate with the newly appointed AFL-CIO representative to Europe.

The Cold War is ending and the global economy growing. There is a pressing need for unions to build new lines of communication across borders. The meeting with the CGT was a small, first step in that direction.

\title{
Seventeenth Annual Southwest Labor Studies Conference: Labor in the Era of World War II
}

\author{
Lorin Lee Cary \\ University of Toledo
}

The Southwest Labor Studies Association met for its seventeenth annual meeting on March 22 and 23, 1991 in Stockton, California at the University of the Pacific, where the organization was founded in 1975. Some one hundred academics, labor and community activists, retirees, students and a few unemployed persons attended. 
About two-thirds of the sessions related to the general theme of "Labor in the Era of World War II." Robert Zieger, a presenter at the first convention and now professor of history at the University of Florida, opened the conference with an address on "The CIO and the National Security State." He stressed how differently Walter Reuther viewed that relationship than did John L. Lewis and Philip Murray. Reuther shared few of their qualms, embraced the state, viewed it as an instrument that labor participation could mold.

Marilyn S. Johnson (Southern Methodist University) and James Gregory (UC, Berkeley), presented papers on the theme of "Changing Demographics and the Work Force: Northern California and World War II." Johnson's paper focused on "Wartime Shipyards: The Transformation of Labor During World War II," while Gregory presented some of his findings, chiefly for the post-war period about "Okies, Arkies, and Other Southerners: Remaking California's White Working Class." He noted, for instance, that by 1970 Okies and other southerners comprised about 20 percent of the skilled and semiskilled labor force. During the 1960s their presence influenced white working-class culture and politics-evident in the popularity of country music and the conservative populism behind votes for George Wallace and other backlash candidates.

A session on "Wartime Federal Labor Regulations" featured papers by Richard P. Boyden (National Archives, Pacific Sierra Region) on "The San Francisco Machinists and the National War Labor Board," and by James B. Atleson (University of Buffalo School of Labor) on "The Wartime Regulation of Labor and the Law of Collective Bargaining."

David Oberweiser, Jr. discussed the diversity within the "San Francisco Ship Scalers and Painters Union." Nancy Quan-Wickham (Berkeley) focused on "The Struggle for Job Control in the ILWU during World War II," and boilermaker Joe Blum discussed his union's policies toward blacks during the war.

Lyle Fulks (Amalgamated Transit Union Local 1277), Jim Daugherty (a retired union official), and Myrna Donahoe (CSU, Dominguez Hills) discussed Los Angeles labor during World War II. A session on "Race, Bay-area Labor, and World War II" included papers by Delores Nason McBroome (Humboldt State University) on "African-American Strategies to Combat Housing Discrimination in California's East Bay during World War II," Shirley Ann Moore (CSU, Sacramento) on "Black Women Workers in Richmond [East Bay] during World War II," and Howard A. De Witt (Ohlone College) on "The San Francisco Filipino Community during World War II." Moore showed how the savings some black women accumulated permitted them, despite being fired by Kaiser, to lay the base for a move into the middle class.

A number of sessions touched on other topics. Philip Mellinger (El Paso Community College) discussed "AFL, IWW and WFM Coexistence in Bingham Canyon, Utah, 1904-08," detailing patterns of WFM-AFL and even IWW-AFL cooperation. Such cooperation, Joe Conlin (CSU, Chico) commented, may be explained by the fluctuating loyalties, overlapping memberships, and "tiny 
worlds" involved. Julie Greene (University of Missouri, Kansas City) and Dana Frank (University of Missouri, St. Louis) presented papers which, as David Brundage (UC, Santa Cruz) pointed out, manifest the renewed emphasis among labor historians on the dominant institutions of the labor movement. Greene probed the AFL's shift from a rejection of party politics and working-class mobilization to a 1906-1908 campaign to mobilize workers behind the Democratic Party. She argued the National Association of Manufacturers' open shop campaign, 1900-1913, closed the option of non-partisan lobbying. Frank's examination of race relations in the Seattle labor movement, 1915-29, uncovered patterns of inclusion which hinged less on ideology than economic threats to established unions and the power of independent Japanese unions.

Three case studies related to "Labor and the Left, 1930s to 1950s." Walter Yonn (AFSCME) provided an insider's view of "The San Francisco CIO and the 1948-50 Purge." The ideological debates of the era, his work suggests, according to Bob Zieger, little reflected the actual political affiliations or interests of the memberships of the unions represented on the council. Michael Witty (University of Detroit), in absentia, focused on the career of Nat Ganley, a Detroit-area communist activist in the UAW and leader of the important UAW Local 155. Dorothy Doyle (Los Angeles Southwest College) read portions of her novel, Journey Through Jess, which deals with the political, racial, and gender dilemmas and tribulations of World War II-era communists and their allies in California.

Several sessions addressed issues relating to agricultural workers. Hub Segur (University of Redlands) examined "The Organizing Success of Filipino Farm Workers in the '30s and '40s," stressing the creation of organization based on linking economic, cultural, and social issues with militant actions and cooperative ventures. Carol Zabin (University of California, Davis), in absentia, dealt with the continuing influx of immigrant workers at the lowest rungs of agricultural labor. "Organizing California Agricultural Workers after World War II" focused on the National Farm Labor Union, AFL. Bill Becker, an NFLU organizer between 1949 and 1952, recalled his experiences in the San Joaquin and Imperial valleys at a time when the presence of braceros and "illegals" hindered organizing. Carolos Muñoz (UC, Berkeley) examined scholar-organizer Ernesto Galarza. A final session brought together several migrant farm workers, members of Proyecto Laboral Agricola and Familias Compesinas, who discussed current efforts to collectively address exploitative conditions.

A panel discussion on the need for a California labor history textbook featured Bob Cherny (San Francisco State University), Dan Cornford (CSU, San Jose), Vicki Ruiz (UC, Davis), and Jeff Lustig (CSU, Sacramento). They noted the paucity of literature on the subject, debated the value of chronological and topical breakdowns, and stressed the significance of ethnicity in the California labor force.

Three panelists commented on different approaches to labor studies. Frank Stricker (CSU, Dominguez Hills) discussed the use of 1930 s films for the teaching 
of class and individualism. Lorin Cary (University of Toledo) commented on oral history. And Mary Tyler (Southern California Library for Social Studies) detailed the development of a labor walking tour of Los Angeles.

Finally, the association continued its tradition of honoring for distinguished lifetime service to the labor movement an individual who has worked in or been associated with the location of the annual meeting. This year the award went to Delores Huerta of the United Farm Workers. John Fernandez, her brother, accepted the award on her behalf.

\title{
Organization of American Historians
}

\author{
Sarah Heath and Thomas Winter \\ University of Cincinnati
}

The panels on labor history at the 1991 OAH convention, held in Louisville in April 1991, offered a diverse range of topics. The sessions included "Video Production and Historical Interpretation: Commemorating a Century of Mine Workers' History," "Women, Work, and Family," "For Fun and Profit: Industrial Recreation in the Mid-Twentieth Century," "Labor and the State: The Exigency of Power," "The Politics of Labor in the Wilson Presidency," and "Records in the National Archives Relating to Twentieth-Century Protest and Dissent."

Several sessions gave evidence of the great interest in the topics of race, gender, and language among the profession. Several sessions addressed the history of Spanish-speaking peoples: "Working beyond Borders: Mexican Migrant Workers," and "Explorations in Chicano Labor History." On the panel "New Directions in Chicano and Filipino History," Jeffrey Garcilazo, speaking about "Mexican Railroad Workers in Kansas and the Southwest," argued that class and race determined the status of these workers and relegated them into being an industrial reserve army. Irene Ledesma, delivering a paper on "Gender and Labor Activism in Texas," argued that in the 1930s Mexican-American women began to transcend their passive, race and gender-determined role in the labor movement and created a public sphere of activism. Arlene deVera's paper on "McCarthyism and WestCoast Filipino Labor Organizing" illustrated how the courts and the INS used redbaiting to crush a local union by deporting the leaders.

At the session "The Politics of Exclusion and Working-Class Relations in the New South," Eric Arnesen, in his paper "Segmentation, Exclusion, and WorkingClass Race Relations in the New South," examined the Railroad Brotherhood's attempt to create a "Nordic closed shop." Arnesen argued that blacks' own racial consciousness served to mobilize a class awareness, which, in turn, functioned as a racially unifying factor. Dana Frank, talking about "Race, Class, and the Politics 